\title{
Nature in Economics
}

\author{
Partha Dasgupta
}

Accepted: 15 October 2007 / Published online: 11 December 2007

(C) Springer Science+Business Media B.V. 2007

\begin{abstract}
Nature has been ill-served by 20th century economics. When asked, economists acknowledge nature's existence, but most would appear to deny that she is worth much. If ecologists worry about the contemporary nexus between population size (and growth), the standard of living, and the natural environment, we economists point to the accumulation of capital and technological progress and say Malthus got it wrong. In this paper I show by an appeal to theory that economics has been so badly misused, that it has deflected attention from deep problems at the nexus that are faced both regionally and globally.
\end{abstract}

Keywords Natural capital · Ecosystems · Inclusive wealth · GDP · Social well-being · Social discount rates $\cdot$ Population growth

\section{Nature's Absence from Growth Theories}

Nature did not appear much in twentieth century economics, and it doesn't do so in current economic modelling. When asked, economists acknowledge nature's existence, but most deny that she is worth much. I have professional colleagues who believe that the services nature provides amount at best to $2-3 \%$ of an economy's output, which is the share of agriculture in the GDP of the United States. Why, they ask, should one incorporate a capital asset of negligible importance in macro-economic models of growth and distribution? Growth modellers note that investment in knowledge enjoy cumulative returns because the benefits are durable and can be shared collectively. So they stress that new ideas are the main source

Text of the President's introductory remarks at the proceedings of Section F (Economics) of the BA (British Association for the Advancement of Science) Festival of Science 2006, at the University of East Anglia, September 2006.

P. Dasgupta $(\bowtie)$

Faculty of Economics, University of Cambridge, Austin Robinson Building,

Sidgwick Avenue, Cambridge CB3 9DD, UK

e-mail: Partha.Dasgupta@econ.cam.ac.uk 
of material progress and imagine that the growth of ideas is capable of circumventing any constraint nature may impose on the ability of economies to grow indefinitely. ${ }^{1}$

One class of growth models assumes that technological progress can be expected to be of such a character that, in alliance with the accumulation of reproducible and human capital it will be able to substitute for a vanishing natural resource base-we will call the latter, natural capital - and generate indefinite growth in output, both in the form of material goods and services. I find it hard to give credence to such models, because a vanishing resource base would mean a dwindling supply of the multitude of ecosystem services upon which life depends. More commonly, growth models assume nature to be a fixed, indestructible factor of production (Ricardo's "land"), implying that in the face of technological progress, the shadow price of natural capital will remain small. The problem with that assumption is that it is simply wrong: nature consists of degradable resources (soil, watersheds, fisheries, fresh water, the atmosphere-ecosystems generally). It would have been reasonable to make that wrong assumption when natural-resource constraints didn't bite, but it isn't reasonable when studying development possibilities open to the world today. Recent concerns over global climate change are perhaps the first acknowledgement among economists that at the scales at which the world economy has been operating for some time, nature is in many aspects, fragile. Moreover, property rights to natural capital are often either vaguely defined or weakly enforced, meaning that nature's services are underpriced in the market. Official statistics on national income certainly give the impression that natural capital is of small importance; but official statistics reflect market prices, not shadow prices. Applied case studies of local ecosystems suggest that if shadow prices were to be used in national and international statistics (as they ought ideally to be), the decomposition of national income into its various factors would look quite different. ${ }^{2}$ Moreover, as nature's services are underpriced in the market, new technologies would be expected to remain rapacious in their use of natural capital: inventors and innovators would have little reason to economize on their use.

In any event, we should be sceptical of a theory that places such enormous burden on an experience that is not much more than 250 years old. Extrapolation into the past is a sobering exercise: over the long haul of history (a 5000 years stretch, say, upto about 250 years ago), economic growth even in the currently-rich countries was for most of the time not much above zero. The study of possible feedback loops between poverty, population growth, and the character and performance of both human institutions and natural capital is not yet on the research agenda of modern growth economists. Which is probably why environmental and resource economics-let us call the subject, ecological economics-remains somewhat isolated from the main body of contemporary economics, especially as the discipline is presented in textbooks and journals.

The focus in international discussions on the world's economic outlook is, justly, on economic growth and distributive justice; but a common afterthought to those discussions, that "the environment must be protected", reflects a widespread belief that nature is a luxury and not an essential factor of production. For example, The Economist (25 September 1999) carried a 38-page Survey of the World Economy in which natural capital made no appearance in the authors' assessment of what lies ahead. I doubt though that many readers will have noticed this. Even today natural capital has not entered our common economic language.

1 Barro and Sala-i-Martin (2003) and Helpman (2004) provide excellent examples.

2 For example, it can be argued that in view of the deep uncertainties that we harbour about the economic effects of global climate change, the shadow price of a ton of carbon dioxide in the atmosphere is currently in the order of 100 US dollars. 
Ecosystems are capital assets. Like reproducible capital assets (roads, buildings, and machinery), ecosystems depreciate if they are misused or are overused. But they differ from reproducible capital assets in three ways: (1) depreciation of natural capital is frequently irreversible (or at best the systems take a long time to recover), (2) except in a very limited sense, it isn't possible to replace a depleted or degraded ecosystem by a new one, and (3) ecosystems can collapse abruptly, without much prior warning. To illustrate problems facing the world's poorest regions today, imagine what would happen to a city's inhabitants if the infrastructure connecting it to the outside world was to break down without notice. Vanishing water holes, deteriorating grazing fields, barren slopes, and wasting mangroves and coral reefs are spatially confined instances of corresponding breakdowns among the rural poor. It can even be argued that ecological collapse, such as the one that has been experienced in recent years in the Horn of Africa and the Darfur region of Sudan, trigger rapid socio-economic decline.

\title{
2 Deficiencies in Economic Reasoning
}

Matters haven't been helped by the misuse of economics by prominent economic journalists, who see economic progress mostly in terms of growth in GDP. It is even today commonly thought that ". . . trade improves the environment, because it raises incomes, and the richer people are, the more willing they are to devote resources to cleaning up their living space." (The Economist, 4 December, 1999, p. 17.) The problem with this viewpoint is that it assumes environmental destruction to be always reversible, flatly contradicting points (1) and (2) above. Moreover, even now the problems the world can expect to face under "business as usual" are set aside by an application of high social discount rates. Once again, here is The Economist (26 June 1999: 128) on social cost-benefit analysis:

\begin{abstract}
"Suppose a long-term discount rate of $7 \%$ (after inflation) is used ... Suppose also that the project's benefits arrive 200 years from now ... If global GDP grows by $3 \%$ a year during those two centuries, the value of the world's output in 2200 will be 8 quadrillion US dollars (a 16-figure number). But in present-value terms, that stupendous sum would be worth just 10 billion US dollars. In other words, it would not make sense for the world to spend any more than 10billion US dollars (under 2 US dollars a person) today on a measure that would prevent the loss of the planet's entire output 200years from now." (Italics mine.)
\end{abstract}

Humanity would cease to exist if world output were zero; so, the scenario we are asked to consider does not remotely resemble a normal investment project. We should therefore be cautious before using the language of standard cost-benefit theory when discussing the choice problem posed by the author. Where the author gets things wrong, even after framing the problem wrongly, is in assuming that the rates to be used for discounting future income losses are independent of the economic forecast. The underlying picture in the passage is that of a Doomsday Project (zero world output in year 2200). Accepting the project would involve a sharp decline in output from some point in time in the future and it can be shown that if consumption were to decline, social discount rates would be negative (Dasgupta 2001 [2004], 2007a). So, where does the 7\% a year discount rate come from? Discounting future incomes produces paradoxes only when it isn't recognized that, as social discount rates are themselves shadow prices, they should be determined on the basis of analysis and not plucked from air. 
I admit to experiencing some pleasure in exposing The Economist's faulty economic reasoning when it comes to environmental matters, not only because the newspaper has for many years been supercilious about matters of the greatest importance and has repeatedly written sermons on how environmental scientists ought to practise their craft, ${ }^{3}$ but also because its writers are (i) highly intelligent, (ii) hugely influential, and (iii) never in doubt. There are, however, deep psychological reasons why people are often ambivalent about environmental matters. The various causes behind contemporary environmental degradation pull in different directions and are together not unrelated to an intellectual tension between the concerns people share about global climate change and international fisheries that sweep across the globe, and about those matters (such as the decline in firewood or water sources in rural areas in the world' poorest regions) that are specific to the needs and concerns of village communities. Environmental problems present themselves differently to different people. In part, it is a reflection of the tension I have just noted and is a source of misunderstanding of people's attitudes. Some people identify environmental problems with population growth, while others identify them with wrong sorts of economic growth. Then there are others who view them through the spectacle of poverty. Each of these visions is correct. There is no single environmental problem; rather, there is an innumerable collection of them. Thus, growth in industrial wastes has been allied to increased economic activity; and in industrialized countries (especially those in the former Soviet Union) and industrializing countries (e.g. India and China), neither preventive nor curative measures have kept pace with their production. Moreover, as noted earlier, the scale of the human enterprise, both by virtue of unprecedented increases in the size of the world's population and the extent of economic activity, has so stretched the capabilities of ecosystems, that humankind can today rightly be characterized as the earth's dominant species. These observations loom large not only in ecological economics, but also in the more general writings of environmentalists and in the professional writings of ecologists in the West. For example, Vitousek et al. (1986) have estimated that $40 \%$ of the net energy created by terrestrial photosynthesis (i.e. net primary production of the biosphere) is currently being appropriated for human use. To be sure, this is a rough estimate. Moreover, net terrestrial primary production isn't exogenously given and fixed; it depends in part on human activity. Nevertheless, the figure does put the scale of the human presence on the planet in perspective.

On the other hand, economic growth itself has brought with it improvements in the quality of a number of environmental resources. The large-scale availability of potable water, and the increased protection of human populations against both water- and air-borne diseases in industrial countries, have in great measure come in the wake of growth in national income these countries have enjoyed over the past 200 years or so. Moreover, the physical environment inside the home has improved beyond measure with economic growth (cooking in South Asia continues to be a central route to respiratory illnesses among women). Such positive links between economic growth and environmental quality often go unnoted by environmentalists in the West. I would guess that this lacuna is yet another reflection of the fact that it is all too easy to overlook the enormous heterogeneity of natural capital, ranging as it does from the atmosphere, oceans, and landscapes, to water-holes, grazing fields, and sources of fuelwood. This heterogeneity needs to be kept in mind.

\footnotetext{
3 See, for example, "Environmental Scares: Plenty of Gloom", The Economist (20 December 1997). The journal Environment and Development Economics reprinted that article in 1998 (Vol. 3, Part 4, pp. 493-499) and published critical comments on it by a number of economists and environmental scientists.
} 


\section{Economic Progress as Sustainable Development}

It can be shown that the right way to judge the economic performance of a country (or for that matter of any economic unit: household, village, district, state, country, the world as a whole) is to study movements in its productive base. By an economy's productive base I mean its institutions and its capital assets. Institutions are different from capital assets, in that the former comprise a social infrastructure (e.g., laws, property rights, beliefs, and the extent of trust among people) for guiding the allocation of resources, including the capital assets themselves. By the latter I mean not only reproducible capital (roads, building, machines), human capital (education, skills, and health), and publicly available knowledge (science and technology), but also natural capital (minerals, oil and natural gas; fisheries, forests, soil; more generally, ecosystems). Let us call the social worth of an economy's productive base its inclusive wealth. An economy enjoys sustainable development if and only if, relative to its population, its inclusive wealth (at constant prices) does not decline. ${ }^{4}$ We call a change in inclusive wealth over time (at constant prices), inclusive investment. The result I am appealing to says that an economy would enjoy sustainable development if and only if, relative to its population, inclusive investment is not negative. ${ }^{5}$ So, by an economy's inclusive wealth we mean the shadow value of its productive base and by inclusive investment we mean the shadow value of the net change in its productive base. Of course, even if some assets have decumulated, inclusive wealth would increase if there were a compensatory accumulation of other assets in the economy. By the same token, even if some assets (e.g. manufactured and human capital) have accumulated, inclusive wealth would decrease if there were a serious decumulation of other assets in the economy (e.g. ecosystem services). Inclusive investment is to be contrasted from recorded investment. Because a wide range of services obtained from natural capital are missing from standard economic accounts, recorded investment could be positive even if inclusive investment were negative. On the other hand, current accounting practice does not recognise that nutrition, health care, and potable water are not merely consumption goods, they are simultaneously investment goods. So, there is a corresponding undercount in recorded investment.

The notion of inclusive investment I am advocating here is not only inclusive of various types of capital assets, but is also sensitive to individual and locational differences. For example, a pond in one location is a different asset from a pond in another, because their ecological characteristics are likely to differ and because the communities making use of them are likely to face different economic circumstances. It follows that seemingly identical ponds should have different shadow prices. Of course, in practice such refinements may not be attainable. But it is always salutary to be reminded that macroeconomic reasoning glosses over the heterogeneity of Earth's resources and the diverse uses to which they are put - by people residing at the site and by those elsewhere. Shadow prices depend not only technology and consumer preferences, but also on institutions, and their combined effect on people's lives. The one powerful message the Millennium Ecosystem Assessment

\footnotetext{
4 See Dasgupta et al. (2000), Dasgupta (2001 [2004]), and Arrow et al. (2003a, b).

5 Those familiar with the Brundtland Commission Report will recognise this as a precise formulation of the definition of sustainable development it adopted, namely, ". . . development that meets the needs of the present without compromising the ability of future generations to meet their own needs." In this reckoning sustainable development requires that relative to their populations each generation should bequeath to its successor at least as large a productive base as it had itself inherited. Notice that the requirement is derived from a relatively weak notion of intergenerational justice. Sustainable development demands that future generations have no less of the means to meet their needs than we do ourselves; it demands nothing more.
} 
(see Reid et al. 2005) has given to us economists is that estimating shadow prices of natural capital assets is now of central importance.

Even if an economy satisfies the sustainablity criterion (viz., that, relative to population, inclusive investment is not negative) today, or has satisfied the criterion in the recent past, it might not continue to do so in the future. Whether it is able to do so depends on the scale of the economy (as measured by, say, GDP), among other things. If the scale becomes too large relative to the natural capital base of the economy, the economy will be unable to maintain its inclusive wealth. As an economy's scale increases, natural capital (e.g. ecosystems) becomes more scarce relative to the size of the economy. Consequently, the amount of other types of capital needed to substitute for natural capital - that is, the shadow prices of natural capital - may rise. The extent to which those shadow prices rise depends on a number of factors, including the rate of technological progress. There can even come a point where no amount of feasible investment in manufactured capital or human capital can offset further declines in natural capital (Ehrlich and Goulder 2007).

It is easy to see why GDP won't do as an index of sustainable development. An economy's productive base will shrink if its stock of capital assets depreciates and its institutions aren't able to improve sufficiently to compensate for that depreciation. GDP is an acronym for gross domestic product. The word "gross" means that GDP ignores the depreciation of capital assets. It is certainly possible for a country's productive base to grow while its GDP increases, which is no doubt a path of economic development we all would like to follow; but it is also possible for a country's productive base to shrink during a period when GDP grows. (For illustrations of such possibilities from recent economic history, see Dasgupta 2007a,b.) The problem is that no one would notice the shrinking if everyone's eyes were rivetted on GDP. If the productive base continues to shrink, economic growth will sooner or later stop and reverse sign. The standard of living will then decline, but no one would have suspected that a fall was in store. So, growth in GDP per head can encourage us to think that all is well, when it isn't. Similarly, it is possible for a country's Human Development Index (HDI) to increase even while its productive base shrinks (Dasgupta 2007a,b). This means that HDI too can mislead. The moral is telling: GDP (or for that matter, the HDI) is not a measure of long run human well-being, meaning that movements in GDP (or for that matter, HDI) are a poor basis for judging economic progress.

\section{Collaboration Among Environmental Scientists and Economists}

The advances that have taken place in ecological economics in recent years have owed much to collaboration between ecologists and economists. ${ }^{6}$ Among those advances is a heightened awareness of the ubiquity of non-linearities in ecological processes and the inability of the price mechanism - even a complete specification of property rights— to allocate resources efficiently.

The good news is that climate change is at last on the international agenda, but there is a danger that such other critical issues as habitat destruction, biodiversity loss, and population growth will remain on the sideline. Which is why, as President of Section F (Economics) of the BA (British Association for the Advancement of Science) Festival of Science 2006, held at the University of East Anglia, I thought it desirable to invite economists and environmental scientists to the Section's customary day-long session to add to the public understanding of

6 See Arrow et al. (1995, 2000, 2004), Perrings (1995), Daily et al. (1998, 1999), Levin et al. (1998), Dasgupta et al. (2000), Heal et al. (2004), and Ehrlich and Goulder (2007). 
ecological economics. The papers that follow are based on the lectures that were delivered on that occasion. The lectures and the discussions that followed them were stimulating and informative. Above all, the day's events illustrated the point that in order that the public is informed of environmental problems and their possible solutions, it is necessary to bring environmental scientists and economists together.

\section{References}

Arrow KJ, Bolin B, Costanza R, Dasgupta P, Folke C, Holling CS, Jansson B-O, Levin S, Mäler K-G, Perrings C, Pimentel D (1995) Economic growth, carrying capacity, and the environment. Science 268(5210):520-521

Arrow KJ, Daily G, Dasgupta P, Levin S, Mäler K-G, Maskin E, Starrett D, Sterner T, Tietenberg T (2000) Managing ecosystem resources. Environ Sci Technol 34(8): 1401-1406

Arrow KJ, Dasgupta P, Mäler K-G (2003a) Evaluating projects and assessing sustainable development in imperfect economies. Environ Resour Econ 26(4):647-685

Arrow KJ, Dasgupta P, Mäler K-G (2003b) The genuine savings criterion and the value of population. Econ Theory 21(2):217-225

Arrow KJ, Dasgupta P, Goulder L, Daily G, Ehrlich P, Heal G, Levin S, Mäler K-G, Schneider S, Starrett D, Walker B (2004) Are we consuming too much? J Econ Perspect 18(3):147-172

Barro RJ, Sala-i-Martin X (2003) Economic growth. MIT Press, Cambridge

Daily G, Dasgupta P, Bolin B, Crosson P, du Guerny J, Ehrlich P, Folke C, Jansson A-M, Jansson B-O, Kautsky N, Kinzig A, Levin S, Mäler K-G, Pinstrup-Andersen P, Walker B (1998) Food production, population growth, and environmental security. Science 281:1291-1292

Daily G, Soderqvist T, Aniyar S, Arrow KJ, Dasgupta P, Ehrlich P, Jansson AM, Jansson BO, Kautsky N, Levin S, Lubchenco J, Mäler K-G, Simpson D, Starrett D, Tilman D, Walker B (1999) The nature of value and the value of nature. Science 289:395-396

Dasgupta P (2001a [2004]) Human well-being and the natural environment. Oxford University Press, Oxford

Dasgupta P (2007a) Economics: a very short introduction. Oxford University Press, Oxford

Dasgupta P (2007b) Nature and the economy. J Appl Ecol 44(3):475-487

Dasgupta P, Mäler K-G (2000) Net national product, wealth, and social well-being. Environ Dev Econ 5(1\&2):69-93

Dasgupta P, Levin SA, Lubchenco J (2000) Economic pathways to ecological sustainability: challenges for the new millennium. BioScience 50(4):339-345

Ehrlich PR, Goulder LH (2007) Is current consumption excessive? A general framework and some indications for the United States. Conserv Biol 21(5):1145-1154

Helpman E (2004) The mystery of economic growth. Belknap, Cambridge

Heal GM, Walker B, Levin S, Arrow KJ, Daily G, Dasgupta P, Ehrlich P, Mäler K-G, Kautsky N, Lubchenco J, Schneider S, Starrett D (2004) Genetic diversity and interdependent crop choices in agriculture. Resour Energy Econ 26(1):175-184

Levin SA, Barrett S, Anyar S, Baumol W, Bliss C, Bolin B, Dasgupta P, Ehrlich P, Folke C, Gren I-M, Holling CS, Jansson A-M, Jansson B-O, Mäler K-G, Martin D, Perrings C, Sheshinsky E (1998) Resilience in natural and socioeconomic systems. Environ Dev Econ 3(2):222-235

Perrings C (ed) (1995) Biodiversity loss: economic and ecological issues. Cambridge University Press, Cambridge

Reid WV, Mooney HA, Cropper A et al (2005) Ecosystems and human well-being: synthesis. Island Press, Washington

Vitousek P, Ehrlich PR, Ehrlich AH, Matson P (1986) Human appropriation of the product of photosynthensis. BioScience 36(3):368-373 